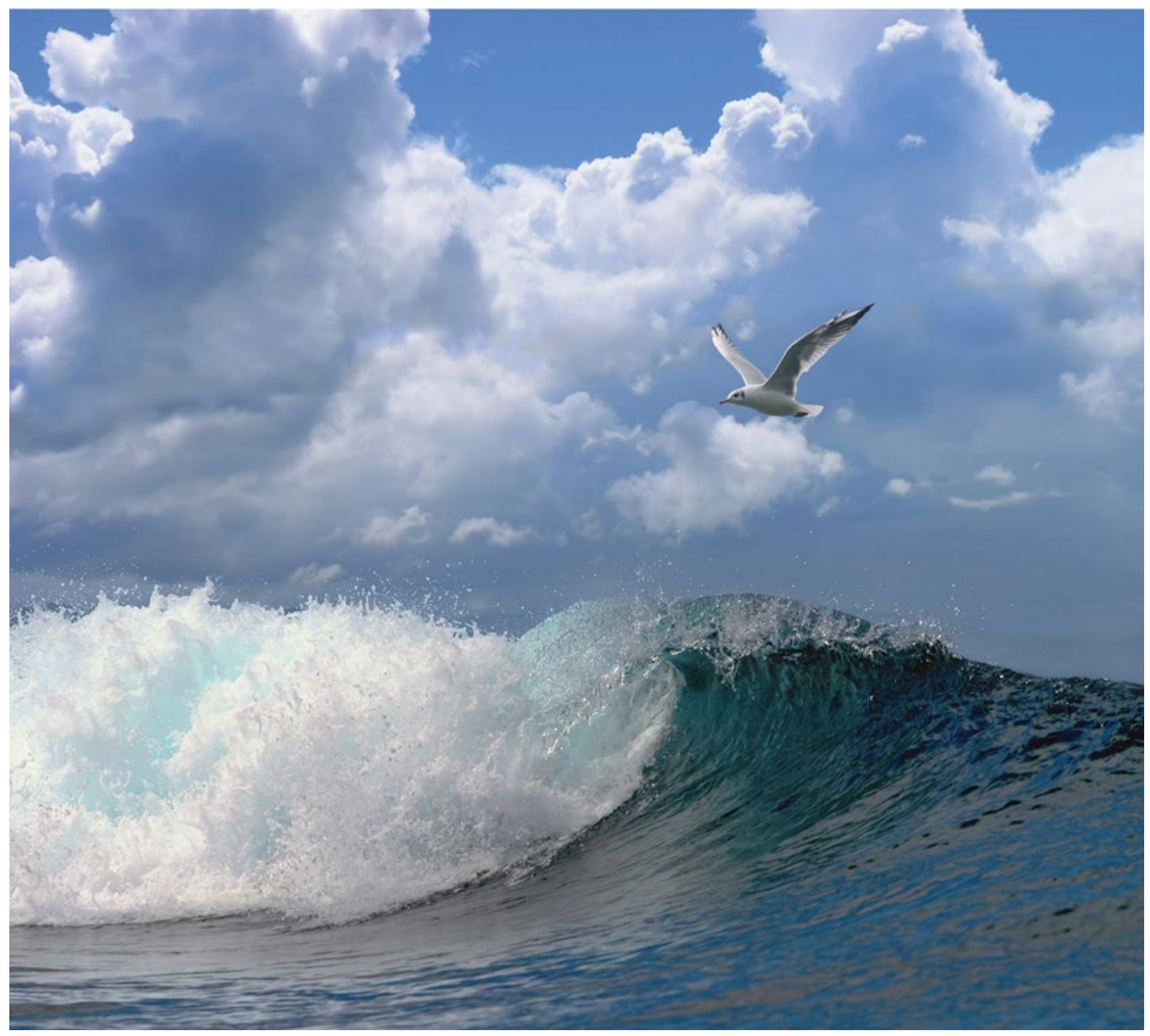

A model approach to estimate the hydrodynamic drag and sediment mobilisation applied to tickler chain beam trawls and pulse beam trawls used in the North Sea fishery for sole

1) Wageningen Marine Research, Wageningen University and Research, PO Box 68, AB IJmuiden 1970, the Netherlands

2) Flanders Research Institute for Agriculture, Fisheries and Food (ILVO), Ankerstraat 1, 8400 Oostende, Belgium

3) National Institute of Aquatic Resources (DTU AQUA), Technical University of Denmark, 2800 Kgs. Lyngby, Denmark

4) School of Engineering, Fraser Noble Building, University of Aberdeen, Aberdeen AB24 3UE, UK University of Aberdeen, Aberdeen Scotland

5) DTU Aqua, National Institute of Aquatic Resources, North Sea Science Park, Hirtshals, Denmark 


\section{A model approach to estimate the hydrodynamic drag and sediment mobilisation applied to tickler chain beam trawls and pulse beam trawls used in the North Sea fishery for sole}

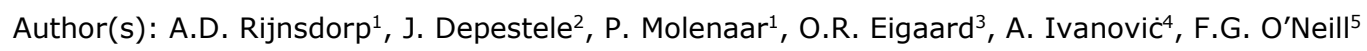

1) Wageningen Marine Research, Wageningen University and Research, PO Box 68, AB IJmuiden 1970, the Netherlands

2) Flanders Research Institute for Agriculture, Fisheries and Food (ILVO), Ankerstraat 1, 8400 Oostende, Belgium

3) National Institute of Aquatic Resources (DTU AQUA), Technical University of Denmark, 2800 Kgs. Lyngby, Denmark

4) School of Engineering, Fraser Noble Building, University of Aberdeen, Aberdeen AB24 3UE, UK University of Aberdeen, Aberdeen Scotland

5) DTU Aqua, National Institute of Aquatic Resources, North Sea Science Park, Hirtshals, Denmark

The multiannual programme Impact Assessment Pulse Fishery was funded by the EMFF, European Fund for Maritime Affairs to the Ministry of Agriculture, Nature and Food Quality and by funding from the Ministry of Agriculture, Nature and Food Quality for the purposes of Policy Support Research Theme.

Project no. BO-43-023.02-004

IJmuiden, June 2020

CONFIDENTIAL: no

Wageningen Marine Research report C056/20 
Keywords: pulse trawl, beam trawl, Sumwing, Pulswing, chainmat, trawling impact.

Client: $\quad$ Ministerie van Landbouw, Natuur- en Voedselkwaliteit

Attn.: Ms. Maddalena Visser

Postbus 20401

2500 EK DEN HAAG

This report can be downloaded for free from https:/doi.org/10.18174/524768.

Wageningen Marine Research provides no printed copies of reports.

Wageningen Marine Research is ISO 9001:2015 certified.

(C) Wageningen Marine Research

Wageningen Marine Research, an institute Wageningen Marine Research accepts no liability for consequential damage, nor within the legal entity Stichting for damage resulting from applications of the results of work or other data Wageningen Research (a foundation under obtained from Wageningen Marine Research. Client indemnifies Wageningen Dutch private law) represented by $\mathrm{Dr}$. Marine Research from claims of third parties in connection with this application. M.C.Th. Scholten, Managing Director All rights reserved. No part of this publication may be reproduced and / or published, photocopied or used in any other way without the written permission

KvK nr. 09098104, of the publisher or author.

WMR BTW nr. NL 8113.83.696.B16.

Code BIC/SWIFT address: RABONL2U

IBAN code: NL 73 RABO 0373599285 


\section{Summary}

1 Introduction

$2 \quad$ Material and Methods

2.1 Beam trawling for flatfish

2.2. Data

2.3. Hydrodynamic drag

2.3.1. Introduction

2.3.2. Catenary

2.3.3. Groundgear

2.3.4. Tickler chains

2.3.5. Chain mats

2.3.6. Electrode arrays and tension relief cords

2.3.7. Net panels

2.4. Sediment mobilisation

3 Results 13

3.1 Tickler chain beam trawls 13

3.2 Pulse trawls 14

3.3 Hydrodynamic drag

3.4 Sediment mobilisation

4 Discussion 18

$5 \quad$ Acknowledgments 21

6 References 22

Annex: Table 1 - 9 


\section{Summary}

Bottom trawls impact the seafloor and benthic ecosystem. To estimate the trawling impact, information is required about the dimensions of the gear that determine their footprint, sediment penetration depth and hydrodynamic drag that determines the amount of sediment mobilised in the wake of the trawl. Here we present the dimension of gear components of the different beam trawls used in the North Sea flatfish fishery including the traditional tickler chain beam trawl, chain-mat trawl and pulse trawls. The hydrodynamic drag of the gears is estimated by summing the drag of different gear components using empirical equations that describe the hydrodynamic drag of different shaped objects, including cylinders, blocks and fish nets. Netting contributes most to the hydrodynamic drag, followed by the ground rope, tickler chains and chain mat. The hydrodynamic drag of bottom components, which determines sediment mobilisation, is estimated at 6.2 and $6.3 \mathrm{kN} \cdot \mathrm{m}^{-1}$ for a traditional tickler chain and chain-mat trawl, and $3.8 \mathrm{kN} . \mathrm{m}^{-1}$ for a pulse trawler. Drag of pulse trawls depends on their rigging and ranges between $2.8-$ $3.2 \mathrm{kN} . \mathrm{m}^{-1}$ for the rectangular ground rope types and $4.0-4.1 \mathrm{kN} \cdot \mathrm{m}^{-1}$ for the sole rope type. The amount of sediment mobilised in a seabed habitat with $20 \%$ silt content is $24 \mathrm{~kg} \cdot \mathrm{m}^{-2}$ for a large tickler chain and chain-mat trawler and between $12-16 \mathrm{~kg} \cdot \mathrm{m}^{-2}$ for a large pulse trawler. 


\section{Introduction}

In the North Sea and other sea areas in the northeast Atlantic beam trawls have been used to target flatfish species, in particular sole Solea solea (Engelhard, 2008; Horwood, 1993). The beam trawl has outcompeted the otter trawl because it allowed fishers to increase the number of tickler chains required to chase sole from the seabed (Daan 1997; Rijnsdorp et al., 2008). The introduction of the beam trawl in the early 1960s initiated an arms race where fishers invested in more powerful vessels to tow larger gear with more tickler chains at a faster towing speed (Rijnsdorp et al., 2008). Chain matrices were deployed in front of the gear to prevent large stones entering the net (Polet and Depestele, 2010). The use of tickler chains and chain mats has raised concerns about the ecological impact of the beam trawl fishery (Jennings and Kaiser, 1998; Kaiser, 2019). Tickler chains disturb the top layer of the sediment, and may inflict mortality among the benthic invertebrate species (Bergman and Hup, 1992; Hiddink et al., 2017; Sciberras et al., 2018). In addition, fine sediments may be brought into suspension in the wake of the gear (Lucchetti and Sala, 2012; O'Neill and Summerbell, 2016) affecting bio-geochemical processes in the sediment - water interface (Puig et al., 2012; Tiano et al., 2019). Finally, the heavy weight gear and high towing speed - up to 7.5 knots (Poos et al., 2013) - result in a high fuel use of about 7500 litres per fishing day (Turenhout et al., 2016).

To reduce the impact of the beam trawl fishery on the sea bed and reduce fuel use, electrical stimulation has been developed to replace mechanical stimulation by tickler chains (Taal and Hoefnagel, 2010; Soetaert et al., 2015b). Electrical stimulation induces a cramp response in the fish that inhibits their ability to escape from the approaching gear (de Haan et al., 2016; van Stralen, 2005). Pulse trawling proved to be an efficient technique and a number of beam trawlers have switched to pulse trawling in the North Sea since 2009 (Haasnoot et al., 2016; Turenhout et al., 2016). The method proved to be particularly efficient for sole which bends in a U-shape making them easy to catch (de Haan et al. 2016; Soetaert et al., 2016a). Comparison of the catch rate of pulse trawl vessels with tickler chain beam trawl vessels fishing at the same time in the same area showed that pulse vessels caught about $30 \%$ more sole, but $40 \%$ less plaice per hour trawling (Poos et al., 2020).

The available evidence shows that a shift from tickler chain beam trawls to pulse trawls may reduce the damage caused by the mechanical stimulation in the fishery for sole due to the reduced depth of penetration of the pulse trawl (Depestele et al., 2016; 2018) and the possible reduction in bycatch of undersized plaice and sole (van Marlen et al., 2014). Studies of the possible negative effects showed that electrical stimulation may cause fractures and haemorrhages in cod and to a lesser degree in whiting (de Haan et al. 2016; Soetaert et al. 2016b) but not in flatfish and seabass (de Haan et al., 2015; Soetaert et al. 2015a; 2016a; 2016c). No negative effects found in two invertebrate species tested (Soetaert et al. 2015a; 2016c).

Since it is illegal to use electricity in catching fish in the European Union, pulse vessels are operating under a derogation aimed to study the possible contribution of this technological innovation to mitigate the adverse ecological effects (Haasnoot et al., 2016). Although the EU decided in 2019 to maintain the ban on pulse trawling, there is a need to resolve the uncertainties about the ecological effects of beam trawling and pulse trawling to support future policy decisions (ICES, 2018b).

The aim of this paper is to contribute to the quantitative assessment of the impact of both conventional beam trawls and pulse trawls (Figure 1). We focus on the estimation of the hydrodynamic drag of the different beam trawls used. The hydrodynamic drag of the trawl is a relevant parameter as it determines the sediment mobilisation of bottom trawling (O'Neill and Ivanović, 2016; O'Neill and Summerbell, 2016). We follow the approach that decompose a gear into gear components, estimate the impact of each component and sum the impact over the components (Paschen et al., 2000; Eigaard et al., 2016). We determine the typical dimensions of the gear components of the beam and pulse trawls used by the commercial fisheries in the North Sea and estimate of the hydrodynamic drag and sediment mobilization of representative fishing gears that can be used in future ecological impact assessments. Although our 
study is focussed on beam trawling, the developed approach is generic and can be used to estimate the sediment mobilization of bottom trawls in general.
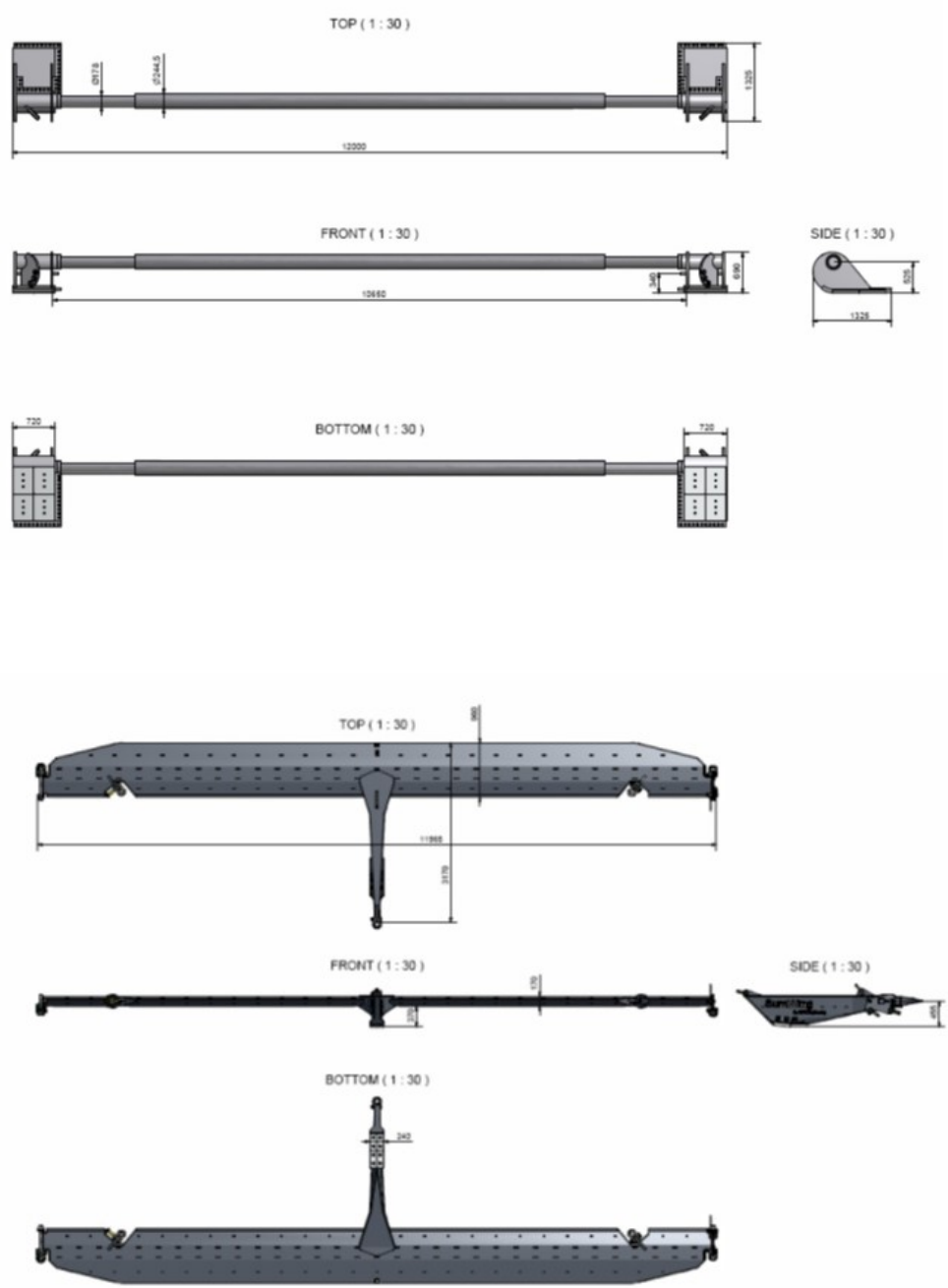

Figure 1. Beam and wing used to fix the horizontal net opening in the beam trawl fishery for flatfish. Each panel shows the top, front and bottom view as well as the side vie of the shoe and nose (from van Marlen et al., 2009). 


\section{$2 \quad$ Material and Methods}

\subsection{Beam trawling for flatfish}

In the eastern Atlantic, flatfish are mainly caught by specialised outrigger vessels - beam trawlers - that deploy two beam trawls, one on either side of the vessel. Among the flatfish, sole and plaice are the main target species by value and weight, respectively (Gillis et al., 2008). Beam trawls are also used in the fishery for brown shrimps but these are not considered in the current report.

There are two types of beam trawlers with regard to the fixation of the horizontal net opening. Figure 1 illustrates the two types that are currently being used in the commercial fishery. The conventional type is a beam trawl in which the horizontal net opening is fixed by an iron beam that rest on two shoes (de Groot and Lindeboom, 1994; Lindeboom and de Groot, 1998). The other type (Sumwing) uses a wing to fix the horizontal net opening. The wing improves the streamline and reduces both the hydrodynamic drag and fuel consumption (van Marlen et al., 2009; Taal and Klok, 2014). The nose of the wing, attached to the front side, follows the seafloor to maintain the position of the wing just above the seafloor (Polet and Depestele, 2010). The wing replaced the conventional beam trawl in the Dutch fleet since its introduction in 2008 and reduced the fuel consumption by approx 16\% (Turenhout et al., 2016). In the Belgium fleet, vessels continued to use conventional beam trawls.
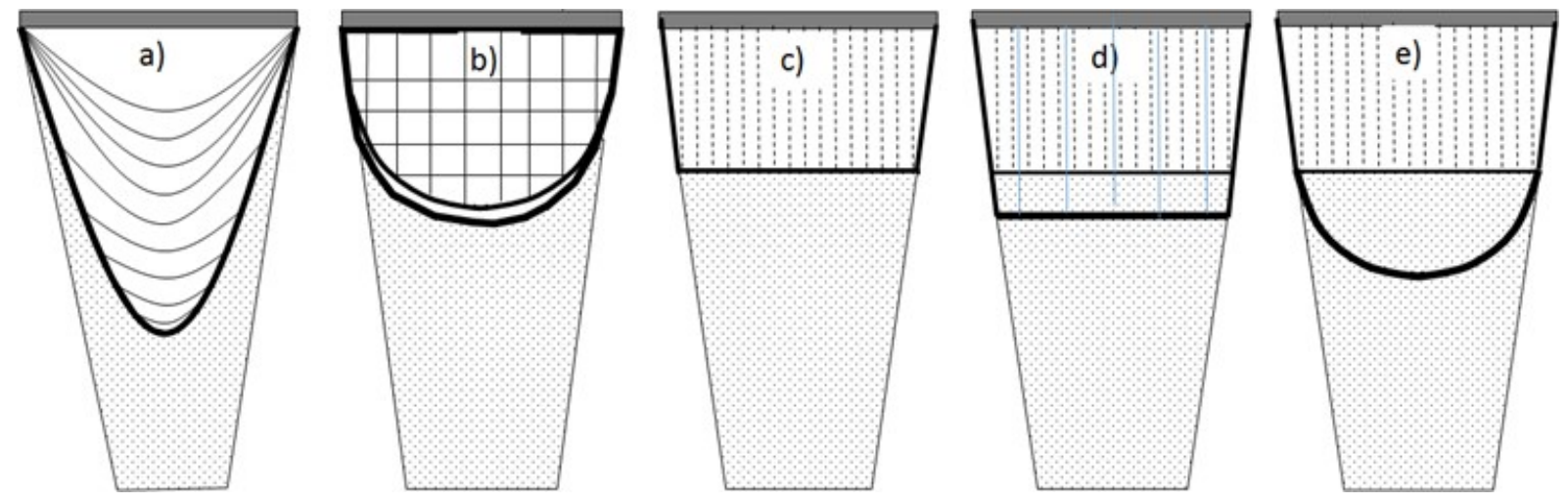

Figure 2. Schematic representation of the different types of beam trawls used in the fishery for flatfish: (a) conventional beam trawl with tickler chains attached to the shoes (shoe ticklers) and to the ground rope (net ticklers); (b) chain mat beam trawl with double ground rope; (c) pulse trawl with rectangular ground rope; (d) pulse trawl with rectangular ground rope and lighter sole rope and sole panel; (e) pulse trawl with $U$-shaped ground rope and lighter sole rope and sole panel. Heavy black lines represent the main ground ropes. Medium black lines represent the sole rope $(d, e)$. Thin lines represent chains of the ticklers (a) and longitudinal and perpendicular chains of the chain mat (b). Hatched lines represent electrode arrays and tension relief cords in pulse trawls ( $c, d, e)$. In (d) additional tension relief cords are used to support the rectangular ground rope The grey horizontal bar represent the beam or wing and the dashed areas represent net panels. The figures do not show the true proportions

The ground rope, netting and stimulation devices can be rigged in different manners. Figure 2 shows the different types used in the flatfish fishery on the continental shelf of western Europe. In the Adriatic, another type with toothed rakes is used to target sole and other benthic fish species (Lucchetti and Sala, 2012). The conventional beam trawl deploys tickler chains attached to the shoes (shoe-ticklers) and the ground rope (net-ticklers) (Figure $2 a$ ). The ticklers chains are equally spaced over the net opening 
(Lindeboom and de Groot ,1998). The number of tickler chains deployed relates to the engine power of the vessel (Rijnsdorp et al., 2008) and varies across sediment types. A second type of beam trawl, the chain-mat trawl, is adapted to be used on hard grounds (Figure $2 \mathrm{~b}$ ). The array of longitudinal and latitudinal chains in the net opening prevent large stones from entering the net. Tickler chains can be added to improve the mechanical stimulation. The chain-mat beam trawl is used by the Dutch vessels fishing in the southern North Sea and by the Belgium beam trawler fleet fishing in the North Sea and other management areas such as the Channel, Irish Sea and Bay of Biscay.

In pulse trawls the mechanical stimulation is replaced by electrical stimulation emitted by a matrix of electrode arrays running from the wing or beam to the ground rope (Figure $2 c-d$ ). In order to operate properly, the electrodes need to be of equal length. The electrodes are equally spaced over the full width of the trawl. To fit this rectangular array, a latitudinal (horizontal) ground rope is required. Different types of ground rope and net were developed to accommodate a latitudinal ground rope. Type 1a combines a rectangular shaped ground rope with either a trouser trawl or a single trawl (Figure 2c). Type $1 \mathrm{~b}$ is similar to type $1 \mathrm{a}$ but with an additional latitudinal ground rope ('sole rope') and netting panel ('sole panel') (Figure 2d). Type 2 uses a U-shaped ground rope with an additional 'sole rope' and netting panel ('sole panel': Figure 2e). Pulse trawls further deploy tension relief cords to maintain the rectangular ground rope shape and release the tension on the electrodes (Figure $2 \mathrm{~d}$ ). In contrast to the electrode arrays, which have physical contact with the sea floor, tension relief cords are running above the seafloor and generally do not touch the sea floor ( $d r$ H. Polet, ILVO, Belgium. unpublished video).

The beam trawl fleet comprises small (maximum engine power of $221 \mathrm{~kW}$ ) and large vessels (maximum engine power of $1467 \mathrm{~kW}$ ) which work under different management constraints. Small vessels are allowed to fish for flatfish with two beam trawls of up to $4.5 \mathrm{~m}$ within the 12 nautical mile zone. Large vessels are allowed to fish with two $12 \mathrm{~m}$ beam trawls.

\subsection{Data}

Technical descriptions of the conventional and chain-mat beam trawls were obtained from enquiries onboard fishing vessels and from direct measurements of chain mat beam trawls in Belgian and Dutch harbours. Enquiries were stratified by large and small vessels and by geographic region (north: UK, HA; middle north: TX, WR, HD, IJM; middle south: SCH, GO; south: VLI, ARM, BR, TH). Chain-mat data enquiry focused exclusively on the southern region where chain-mat beam trawls are more frequently used than in the middle and northern region (Rijnsdorp et al., 2008). The enquiry data was complemented with data obtained from the literature (Fonteyne and Polet 1992; Lindeboom and de Groot, 1998; van Marlen et al. 2014; de Groot and Lindeboom, 1994) and from experiments on the impact of flatfish trawls on the seabed (Depestele et al., 2016; 2019) and the European wide gear inventory (Eigaard et al., 2016).

Information on the pulse trawl gear was available from the Technical Dossier of the pulse trawl vessels (75 vessels). Additional information was obtained from enquiry forms sent out to a sample of Dutch fishing vessels as part of the FP7-project BENTHIS. The sample was stratified by geographic region and vessel size (large: $222 \mathrm{~kW}$ - $1471 \mathrm{~kW}$; Euro cutters: <=221 kW). The skippers were asked to provide information on the pulse gears currently in use as well as of the tickler chain gear used prior to the switch to pulse trawling. 
The information is used to make a quantitative description of the tickler chain beam trawl and chain-mat trawl representative for the gears used at the start of the transition phase around 2010, and the Sumwing trawl and pulse trawls representative for the gears used around 2015. There is one gear component - chafe ropes for trawl belly and codend protection - that was not taken into consideration in our study. Chafe ropes are widely used by demersal bottom trawlers to protect the belly of their nets for wear. No measurements, however, have yet been made of the hydrodynamic drag of this gear component.

The towing speed of the different gear types and vessel size classes is estimated from the distinct peak in the frequency distribution of the observed speeds in the VMS dataset (Hintzen et al., 2010; Poos et al., 2013).

\subsection{Hydrodynamic drag}

\subsubsection{Introduction}

The hydrodynamic drag of a body is a function of the projected frontal area $A_{f}\left(\mathrm{~m}^{2}\right)$ of the body in the towing direction, the towing speed $U\left(\mathrm{~ms}^{-1}\right)$, the hydrodynamic drag coefficient of the body $C_{D}$ and the density of water $\rho\left(\mathrm{kg} \cdot \mathrm{m}^{-3}\right)$ and is expressed as

$$
D=0.5 \rho A_{f} U^{2} c_{D}
$$

The hydrodynamic drag coefficient is a dimensionless quantity that depends on the geometry of the body, the Reynolds number and the surface roughness. Table 1 provides the coefficient for different gear elements. There has been much research done of the drag coefficient of bodies with basic geometric shapes such as circular cylinders, cubes and spheres and many experiments have been carried out to measure them (Hoerner, 1965). These experiments have usually been carried out for bodies that are towed obliquely. Hoerner (1965) shows that when cylinders are towed at an angle to the flow, the 'crossflow' principle applies and that the hydrodynamic pressure forces only correspond to the velocity component in the direction normal to their axis. He demonstrates that the resulting drag on a cylindrical section of diameter $\mathrm{d}$, length $\mathrm{I}$ and angle of attack $\alpha$ is given by

$$
D c=0.5 \rho U^{2} d l c_{D} \sin ^{3}(\alpha)
$$

where $C_{D}$ is the drag coefficient of the component when it is towed obliquely (ie $\alpha=0$ ). This formulation is appropriate when the cylinder is relatively long i.e. when $l>>d$, and here we use it to estimate the drag of sections of chains and groundgears.

To apply these equations we need to know the towing speed, the drag coefficient, the frontal area and the angle of attack of the individual components.

As mentioned above, the towing speed of a particular gear can be estimated from VMS data. Very little is known, however, regarding the drag coefficients of beam trawl components. Here, for chains, we use values calculated by Xu and Huang (2014), and for some of the ground gear components, we use measurements made by O'Neill and Summerbell (2016). Where measurements do not exist we use those that have been made for similarly shaped objects such as cylinders, disks, cubes and spheres etc (Hoerner, 1965). 
The frontal area and angle of attack of components such as the shoes, roller wheels, beam and nose of wing are well defined and readily measurable, whereas those for components such as the ground gears, tickler chains, chain mats and electrodes are more variable and depend of the rigging of the gear. Therefore, we need to look at these components in more detail.

\subsubsection{Catenary}

A chain or ground rope that is hanging freely from two points will form a catenary and this curve is often used to approximate the geometry of ground ropes and tickler chains as they are towed across the seabed (Sangster and Breen, 1998). The $x$ - and $y$-coordinates of a catenary of length $(L)$ and distance $(D)$ between the hanging points is given by

$y=a \cosh \left(\frac{x}{a}\right)$

where $a$ is a solution to

$2 a \operatorname{asinh}\left(\frac{L}{2 a}\right)=D$

and can be determined using optimisation routines such as the R function "optimize" when $L$ and $D$ are known (Brent, 1973).

\subsubsection{Groundgear}

We assume that the $\mathrm{U}$-shaped groundgears of Figure $2 \mathrm{a}, 2 \mathrm{~b}$ and $2 \mathrm{e}$ form catenaries where $L$ is the groundgear length and $D$ is the beam width. To estimate their hydrodynamic drag, we subdivide them into 100 piecewise linear segments and calculate the drag of each segment using equation [2].

The 'rectangular' groundgear comprises of two (almost) longitudinal sections and one latitudinal one (Figure 2c and 2d). Given their lengths, we can calculate the length and angle of attack. The hydrodynamic drag is then calculated as the sum of the drag of the three sections using equations [1] and [2].

\subsubsection{Tickler chains}

We also assume that the tickler chains form catenaries. Tickler chains can be grouped into two main categories: those that are attached to the shoes or beam (shoe ticklers) and those that are attached to the groundgear or footrope (net ticklers). The distance between the attachment points of shoe ticklers is the beam width but for the net ticklers it varies. There is little information available on the length of the net ticklers and the distance between their attachment points. Nevertheless, given that they are deployed such that they are distributed evenly between the ground rope and the beam, we estimated the length of chain $i$ to be

$L_{i}=l_{\min }+(i-1) *\left(l_{\max }-l_{\min }\right) /(n-1)$

where $n=$ number of tickler chains and $l_{\max }\left(l_{\min }\right)=$ median value of the largest (smallest) length observed (shoe tickler: $l_{\max }=25 \mathrm{~m}$ and $l_{\min }=18 \mathrm{~m}$; net tickler: $l_{\max }=14$ and $l_{\min }=3.5 \mathrm{~m}$ ). For the net ticklers, the position of the attachment points was estimated from the intersection of the groundgear and the tickler chain catenaries. As for the groundgears, the tickler drag was found by estimating the drag of 100 piecewise linear section using their respective length $l$ and angle of attack $\alpha$ in equation [2]. 


\subsubsection{Chain mats}

A chain mat comprises of a matrix of longitudinal and latitudinal chains that are attached to the ground rope and the beam. Information was available on the number and diameter of the longitudinal and latitudinal chains but not on their length. The lengths of the chains were estimated from the vertical distances between the point of attachment along the groundgear catenary and the beam (longitudinal chains) and the horizontal distances between the points of attachment (latitudinal chains). The points of attachment of the chains along the groundrope catenary were determined by distributing them equally over the width of the trawl. The drag of the latitudinal chains were estimated using equation [1] and that of the longitudinal chains using equation [2] where $\alpha=$ asin(height of the beam above the sea bed /chain length).

\subsubsection{Electrode arrays and tension relief cords}

Electrodes and tension relief cords are attached to the beam or Sumwing and run in the towing direction. The conductor section of the electrodes is in contact with the seabed, hence the length above the seabed is the total length of electrode array ( $\left.I_{\text {tot }}\right)$ minus the length of the conductors and isolator parts ( $I_{\text {cond }}$ ). The angle of attack of this section is given by

$\alpha_{e}=\operatorname{asin}\left(h /\left(I_{\text {tot }}-I_{\text {cond }}\right)\right)$

Additional drag is generated by the isolating parts that generally have a larger diameter $\left(d_{1}\right)$ than the conducting parts of the electrode array $\left(d_{2}\right)$. This component is estimated as the product of the number of conducting parts $\left(n_{c}\right)$ and the difference in frontal surface areas of the isolator and the conductor.

$A=n_{c} n\left(d_{1}^{2}-d_{2}^{2}\right) / 4$

To estimate the drag of the tension relief cords we assume that they run in a straight line between the beam or Sumwing at height $\mathrm{h}$ and the ground rope, and consequently their angle of attack is

$\alpha_{t r c}=\operatorname{asin}\left(h / I_{t r c}\right)$

A drag coefficient of 0.8, applicable for blunt shaped cylinders in axial flow (Hoerner, 1965), is used for the electrode part that is in contact with the sea floor. For the other part and the tension relief cords the drag coefficient of 1.1 for cylinders is used.

\subsubsection{Net panels}

There has been a lot of research undertaken on the hydrodynamic drag of netting panels at specific angles of attack and for given solidity and hanging ratios (Zhou et al., 2015). To use that information here would require a detailed understanding of the netting geometry as the gear is being fished, and which in general is not available. Hence we use the results of MacLennan (1981), who found the following dependence of netting drag on the twine surface area, $A$, and towing speed, $U$, from experimental trials with a number of trawl gears

$$
D_{n}=\frac{0.5 \rho * U^{2} * A * 0.352}{1+0.125 U}
$$

The twine surface area is estimated from 


$$
A=\left(N_{t}+N_{b}\right) N_{d} M d
$$

where $N_{t}$ is the number of meshes on the top row of a panel, $N_{b}$ the number on the bottom row, $N_{d}$ the number along the length of the panel, $M$, the mesh size and $d$ the twine diameter (Ferro, 1981). The diameter of double braided twine is assumed to be 1.64 times the diameter of one of the component single twines.

\subsection{Sediment mobilisation}

Sediment mobilisation $m$ is calculated from hydrodynamic drag $H_{d}$ caused by the fishing gear and the silt fraction $s_{f}$ of the sediment (O'Neill and Ivanovic, 2016).

$m=2.602 s_{f}+1.206 * 10^{-3} H_{d}+1.321 * 10^{-2} s_{f} H_{d}$
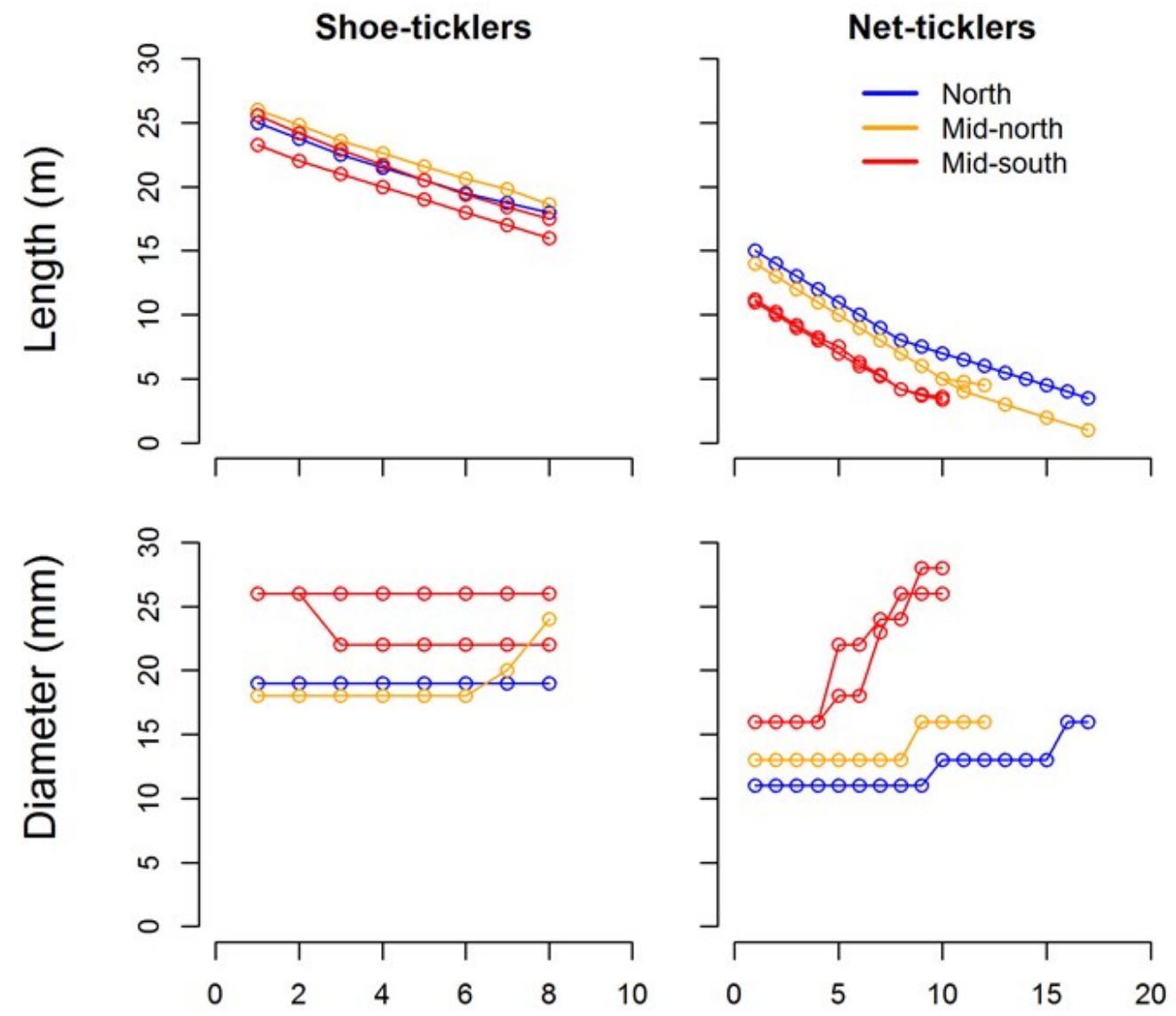

Tickler chain number

Figure 3. Length and diameter of the tickler chains deployed from the shoes and from the net in function of the consecutive number of the chains in tickler chain beam trawlers from three geographic regions. 


\section{Results}

\subsection{Tickler chain beam trawls}

Conventional tickler chain beam trawlers $(>221 \mathrm{~kW}$ ) use a beam of length $12 \mathrm{~m}$ and a diameter of $24 \mathrm{~cm}$ to fix the horizontal net opening. Small vessels $(<=221 \mathrm{~kW}$ ) use a beam length of $4.5 \mathrm{~m}$ and a diameter of $15 \mathrm{~cm}$ in the coastal waters (Table 2), although a few vessels may fish outside the $12 \mathrm{~nm}$ zone with a beam of 7 or 8 meters. The height varies between 50 and $80 \mathrm{~cm}$ with an average height of $70 \mathrm{~cm}$ in large vessels and $60 \mathrm{~cm}$ in small vessels. The beam is attached to two shoes on either side. The median frontal surface area of the shoes is $0.063 \mathrm{~m}^{2}$ in large vessel and $0.054 \mathrm{~m}^{2}$ in small vessels.

Sumwing beam trawlers use a wing to fix the horizontal net opening to $12 \mathrm{~m}$ in large vessels $(4.5 \mathrm{~m}$ in small vessels). The wing is streamlined and has a width of $1.07 \mathrm{~m}(0.94 \mathrm{~m})$ and a maximum height of 20 $\mathrm{cm}(17 \mathrm{~cm})$. In the centre of the wing, a $3.4 \mathrm{~m}(2.9 \mathrm{~m})$ long nose is attached to keep the wing at about $0.45 \mathrm{~m}$ above the sea bed. The part of the nose that is in contact with the sea bed is protected by iron plates of $0.13 \mathrm{~m}^{2}\left(0.07 \mathrm{~m}^{2}\right)$. The frontal part of the nose of $0.036 \mathrm{~m}^{2}\left(0.024 \mathrm{~m}^{2}\right)$ makes an angle of around 45 degrees with the sea bed. Some of the small vessels may fish outside the $12 \mathrm{~nm}$ zone using a wing of 7 or 8 meters.

Vessels fishing with a conventional or Sumwing beam trawl use a U-shaped ground rope and tickler chains (Table 3 ). The ground rope is constructed of a chain with a middle section of about $20 \%-25 \%$ of the length of the ground rope is covered with rubber disks. The mean length of the ground rope is 35.4 $\mathrm{m}$ (range: $34-38.5 \mathrm{~m}$ ) in large vessels and $16 \mathrm{~m}$ in euro cutters. The diameter of the rubber disks decreases from the centre to the edge of the middle section. The tickler chains are attached to the shoes (shoe ticklers) and ground rope (net ticklers) and are evenly spaced in front of the ground rope. Figure 3 shows the number, lengths and diameter of tickler chains deployed by a representative sample of vessels. The four vessels sampled use 8 tickler chains from the shoes and between 10 and 17 net tickler chains. The diameter of the ticklers ranges between $18-26 \mathrm{~mm}$ for the shoe ticklers and $12-28 \mathrm{~mm}$ for the net ticklers. The heavier ticklers are deployed in the shorter net ticklers close to the ground rope. Vessels fishing on rougher grounds in the south use fewer but heavier net-tickler chains.

The dimensions of the chain mat trawl used by Dutch beam trawlers is given in Table 4 . The chain mat comprise of a matrix of longitudinal and perpendicular chains that is attached in the net opening between the beam and the ground rope. In addition to the chain mat, tickler chains can be deployed from the shoes or additional chains can be added to the perpendicular chains of the chain mat ("krauers"). Chain mat beam trawlers use two ground ropes to separately attach the net panel and the chain mat. The ground rope attached to the net panel consists of a chain with rubber discs to protect net. The ground rope attached to the chain mat may consist of a bare chain or a chain with rubbers discs of similar or smaller diameter. The rubber discs of the chain mat ground rope are absent at the points/along the length of the intersection of the ground rope and the chain mat. The independence of the configuration of the chain mat and the trawl net is assured by having two ground ropes, but individual fishers may choose to add a third intermediate ground rope with small rubber discs or as a bare chain to avoid net 
deformation by the chain mat during fishing. The ground rope of the chain mat beam trawlers is shorter than the ground rope used by the tickler chain beam trawlers.

Tickler chain beam trawlers use large meshed top panels of single braided twine. The mesh size decrease from about $300-400 \mathrm{~mm}$ at the front to $80-100 \mathrm{~mm}$ at the back. Bottom panels are generally of double braided twine with a mesh size decreasing from around $100 \mathrm{~mm}$ at the front to $80 \mathrm{~mm}$ at the back. The twine surface area of the net, excluding the cod-end, ranges between 3.74 and $4.73 \mathrm{~m}^{2}$ per meter beam length (Table 5).

\subsection{Pulse trawls}

The different types of pulse trawls used in the Dutch pulse trawl fleet around 2015 are shown in Table 6. Most pulse trawlers, in particular large vessels, use a wing to fix the horizontal net opening (Pulse wing). Euro cutters predominantly use a Pulse beam trawl. The dimensions of the Pulse wing and Pulse beam is presented in Table 2. Pulse trawls can be rigged with a single or a double ground rope. The rectangular ground rope is generally used as a single ground rope (PUL_R). About $25 \%$ of the vessels that use a rectangular ground rope, deploy an additional sole rope and corresponding bottom panel (PUL_R_SR). Vessels deploying a U-shaped ground rope always use an additional sole rope and bottom net panel in order to create a rectangular space for the matrix of electrode arrays (PUL_U_SR).

The length of the ground rope varies among vessels and differ between rigging types (Table 7). Large pulse vessels using PUL_R have the shortest ground ropes (median $=24 \mathrm{~m}$ ), while large vessels using PUL_U_SR have the longest ground rope (median $=30.4 \mathrm{~m}$ ). The small vessels use a $16 \mathrm{~m}$ ground rope. The ground rope generally comprises from a chain $(22-26 \mathrm{~mm})$ that is partly covered by rubber disks (Table 7). The diameter of the disks varies between the ground rope segments and is largest in the centre and becomes smaller towards the wings of the trawl. The rectangular ground rope comprises of a horizontal part and two almost vertical parts that are connected to the beam of wing. The median diameter of the disks is $20 \mathrm{~mm}$ (range: $12-30 \mathrm{~mm}$ ) in the central section (horizontal part) and may decrease to $10 \mathrm{~mm}$ in the vertical segments. Part of the vertical segments of the ground rope that is attached to the shoe or wing is uncovered chain $(22-26 \mathrm{~mm})$. The sole rope used in combination with a rectangular ground rope comprises of a chain $(22 \mathrm{~mm})$ covered with disks with a median diameter of 10 $\mathrm{mm}$ (range $5-15 \mathrm{~mm}$ ).

A typical U-shaped ground rope comprise of a middle part with rubber disks of $24 \mathrm{~mm}$ (range: 18-30 $\mathrm{mm}$ ) in the centre and $18 \mathrm{~mm}$ (range: $10-15 \mathrm{~mm}$ ) at the end and wing segments with rubber disks of a median diameter of around $15 \mathrm{~mm}$ (range: 10-15 mm). The last segment comprises of uncovered chain of 2 to 4 metres that is attached to the Sumwing or beam. The disks of the sole-rope have a median diameter of $15 \mathrm{~mm}$ (range $=10-20 \mathrm{~mm}$ ).

In addition to the main rigging types distinguished, more subtle variations in rigging may occur. For example, eleven vessels use an additional rope with $10 \mathrm{~mm}$ diameter disks in front of the ground rope to enhance the water flow over the rubber discs of the ground rope reducing the water flow passing underneath the ground rope. Twelve vessels use a flip-up rope to avoid catching large stones. The flip-up rope, which has a mesh size of about $40 \times 40 \mathrm{~cm}$ and a rope diameter of about $2 \mathrm{~cm}$, is attached in front 
of the ground rope. This flip-up rope is most common in the south where vessels previously used a chain-mat trawl.

Small differences were observed in the number of electrodes and tension relief cords used. Vessels using a rectangular ground rope deploy 26 electrodes, while vessels using a U-shaped ground rope deploy 24 electrodes. The average distance between electrodes is $41.5 \mathrm{~cm}$ (range $40-42 \mathrm{~cm}$ ) and does not differ between rigging types. The number of tension relief cords attached is generally one less than the number of electrodes. Vessels that deploy a PUL_R_SR use 5 or 11 tension relief cords between the wing and the rectangular ground rope in addition to the tension relief cords between the wing and the sole rope. The conducting and isolating parts of the electrode array have a diameter of $60 \mathrm{~mm}$ and $33 \mathrm{~mm}$, respectively. The diameter of the tension relief cords is $60 \mathrm{~mm}$. The electrode array comprises of alternating electrodes and insulated parts. Two main types of electrode arrays are being used. One type comprises of 11 electrodes of $12.5 \mathrm{~cm}$ length and 10 isolating parts of $22 \mathrm{~cm}$. The other type comprises of four sets of three electrodes of $12.5 \mathrm{~cm}$ and two isolating parts $0 f 13.75 \mathrm{~cm}$, separated by isolating parts of $60 \mathrm{~cm}$ (Soetaert et al. 2019).

The mesh size of the top panels of pulse nets decrease from about $200 \mathrm{~mm}$ at the front to $100 \mathrm{~mm}$ at the back. The bottom panels generally have a mesh size of $100 \mathrm{~mm}$. At the end of the bottom panels a larger meshed panel of about $140 \mathrm{~mm}$ is deployed to release benthos and debris. The estimated twine surface area, excluding the cod-end, is largest in a pulse trawl with a U-shaped ground rope and sole rope $\left(6.7 \mathrm{~m}^{2}\right)$ and smallest in rectangular trouser trawl $\left(5.3 \mathrm{~m}^{2}\right)$, both exceeding the twine surface area of tickler chain beam trawls (Table 5 ).

\subsection{Hydrodynamic drag}

Towing speed differs across gears (Table 8). Large vessels tow their tickler chain trawls at an average speed of $3.29 \mathrm{~m} . \mathrm{s}^{-1}$ as compared to $2.53 \mathrm{~m} . \mathrm{s}^{-1}$ for pulse trawls. The difference in towing speed is less in small vessels: 2.66 and $2.39 \mathrm{~m} . \mathrm{s}^{-1}$, respectively. The towing speed of chain mat beam trawlers is slightly less than tickler chain trawlers but higher than pulse trawlers. The mean towing speed of pulse trawlers does not differ between rigging types (PUL_R: 2.52 +/- 0.07 m.s ${ }^{-1}$; PUL_R_SR: 2.47 +/- 0.0.7 m.s ; $^{-1}$; PUL_U_SR: $\left.2.53+/-0.09 \mathrm{~m} \cdot \mathrm{s}^{-1}\right)$.

Figure 4 shows the hydrodynamic drag of the traditional beam trawl, chain mat trawl and various pulse trawl gears, as well as the contribution of the various gear components. The hydrodynamic drag of pulse trawls of large vessels, taking account of the frequency of occurrence of the different rigging types, is estimated at $6.8 \mathrm{kN} \cdot \mathrm{m}^{-1}$ about $32 \%$ lower than the $10 \mathrm{kN} \cdot \mathrm{m}^{-1}$ of tickler chain trawls (Table 9). For small vessels, the estimated hydrodynamic drag of pulse trawls of $6.0 \mathrm{kN} . \mathrm{m}-1$ is at about the same level as the drag of tickler chain trawls. Net panels contribute most ( $>=70 \%$ in pulse trawl and tickler chain trawls), followed by the ground gear in pulse trawl (10\%) and tickler chains or chainmat in tickler chain trawls (20\%). The contribution of the beam is $1.4 \mathrm{kN} \cdot \mathrm{m}^{-1}$ (about $15 \%$ ) substantially higher than the $0.09 \mathrm{kN} . \mathrm{m}^{-}$

${ }^{1}$ of the Sumwing ( $\mathrm{H}$. Klein Woolthuis, personal communication). The contribution of the electrodes and the tension relief cords, shoes or nose is relatively small. Pulse trawls rigged with an additional sole rope have a higher drag than pulse trawls rigged with a single ground rope. 
The hydrodynamic drag of bottom gear components of a pulse trawl is estimated at $3.8 \mathrm{kN}$. $\mathrm{m}^{-1}$ for large

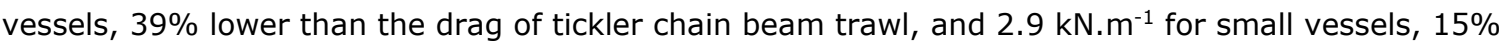
lower than tickler chain beam trawl (Table 9).

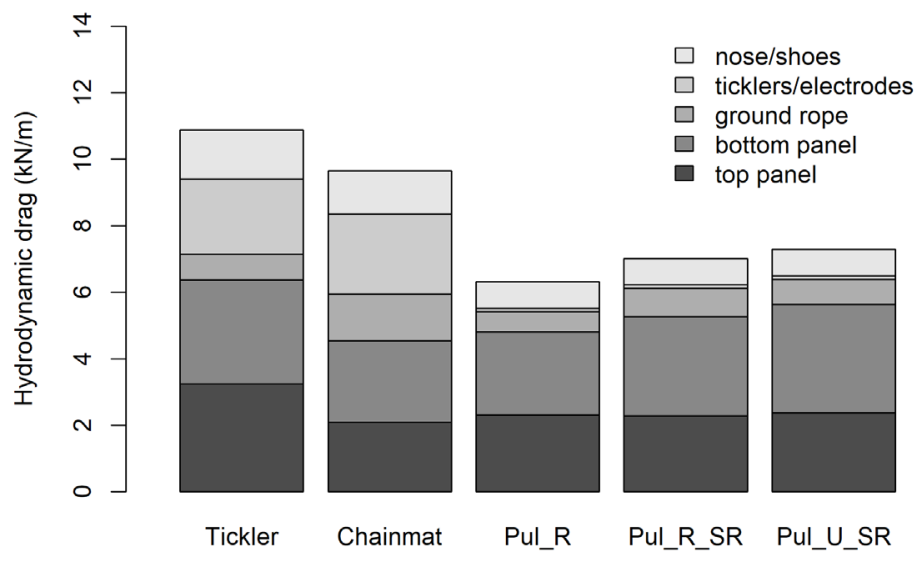

Figure 4. Hydrodynamic drag (kN.m-1) by gear component of conventional beam trawls (tickler chain, chain mat) and different type of pulse trawls (PuI_R: rectangular, Pul_R_SR: rectangular plus sole rope, $U$-shape plus sole rope).

\subsection{Sediment mobilisation}

The amount of particles mobilised in the wake of a beam trawls differ between tickler and pulse trawls and increase with the percentage of silt in the sediment (Figure 5). Tickler chain trawls mobilise around $21 \mathrm{~kg} \cdot \mathrm{m}^{-2}$ when fishing in an area with 20\% silt. The amount of mobilised sediment is reduced to 12 $\mathrm{kg} \cdot \mathrm{m}^{-2}$ when the same habitat is trawled by a pulse trawl with a rectangular ground rope (PUL_R) and to about $15 \mathrm{~kg} \cdot \mathrm{m}^{-2}$ when trawled by a pulse trawl rigged with an additional sole rope and sole panel (PUL_R_SR, PUL_U_SR). 


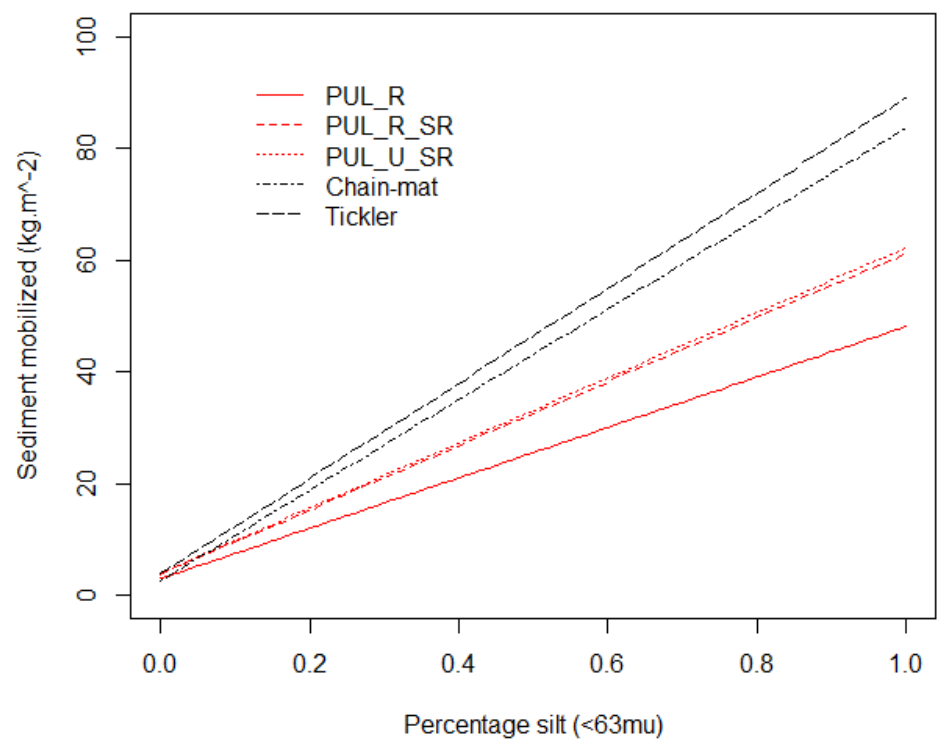

Figure 5. Sediment mobilisation $\left(\mathrm{kg} . \mathrm{m}^{-2}\right)$ by tickler chain beam trawls (chainmat, tickler) and different types of pulse trawl (PuI_R, PuI_R_SR,Pul_U_SR) in relation to the percentage silt in the sea floor sediment 


\section{Discussion}

The methodology used to estimate the hydrodynamic drag is necessarily crude. In many cases the methodology is based on empirical drag measurements on bodies that are geometrically similar to gear components. These empirical estimates are often for idealized cases where the components (i) are towed in mid-water without interaction from the seabed, (ii) are towed directly through the water, at an angle of attack of $90^{\circ}$ and (iii) have a smooth surface. The approach further assumes that the hydrodynamic drag of the individual gear components are additive and that there is no interference between them (Paschen et al., 2000).

The estimated 32\% reduction in hydrodynamic drag of pulse trawls as compared to the conventional tickler chain trawl is in broad agreement with a $46 \%$ reduction in fuel consumption (Turenhout et al. 2016). The reduction in fuel consumption is partly due to the replacement of the beam by a hydrodynamic foil. The introduction of the hydrodynamic foil (Sumwing) reduced fuel consumption by about 16\% (van Marlen et al., 2009; Turenhout et al., 2016) close to the estimated 15\% contribution of the beam to the hydrodynamic drag. The remaining 30\% reduction in fuel use will reflect the decrease in hydrodynamic and geotechnical drag due to the replacement of tickler chains by electrode arrays and the lower towing speed.

The estimated hydrodynamic drag can also be compared to the total drag of beam trawls measured at sea. The estimated hydrodynamic drag is expected to be lower than the measured total drag, because the latter also includes the geotechnical drag. Three studies are available that measured the total drag of a commercial beam trawl over a range of towing speeds and also reported the relevant dimensions of the fishing gear to apply our approach. Blom $(1982,1990)$ studied the drag of a tickler chain beam trawl and estimated the separate contribution of the tickler chains and net, whereas Fonteyne and co-workers studied the contribution of the chainmat and net (Fonteyne, 2000; Paschen et al., 2000). The results show that as expected the measured and estimated drag increases with towing speed although the slope is steeper for the estimated hydrodynamic drag (Figure 6). The shallower slope of the total drag - speed relationship is due to the decrease in geotechnical drag at increasing speeds due to the increase in lift force which, for towing speeds between $3-3.5$ m.s - $^{-1}$ may even lift the gear off the bottom (Blom, 1982, 1990; Fonteyne, 2000). This implies that the measured total drag can best be compared to the estimated hydrodynamic drag at high towing speed when the geotechnical drag component is the lowest.

Figure 6 shows that at a high towing speed of $3.5 \mathrm{~m} . \mathrm{s}^{-1}$ the estimated hydrodynamic drag exceeds the measured total drag by a factor of 1.3-1.6. The discrepancy is mainly due to the estimated hydrodynamic drag of the net. At high towing speed, the estimated hydrodynamic drag of the net is about two times higher than the measured value (Figure $6 \mathrm{~b}$ and $\mathrm{c}$ ). This difference may be due to the fact that the typical beam trawl towing speeds are greater than the maximum speed of approximately $2.5 \mathrm{~ms}^{-1}$ in MacLennan's (1981) experimental data, and that accordingly that the drags estimated here are extrapolations of his relationship. In addition, the discrepancy may also be due to the rectangular shape of beam trawl nets which differs from the more oval, four panel nets, with large headline heights, used by MacLennan (1981) to derive his empirical relationship. The shape of the net will influence the angle of attack of the twine and hence affect the hydrodynamic drag. This inference is supported by the comparison of the drag measurement of a beam trawl gear without tickler chains towed free through the 
water column. When dragged free from the sea floor, the shape of the net will change and will more likely resemble the nets for which MacLennan derived his empirical relationship (MacLennan, 1981). At $3.3 \mathrm{~m} / \mathrm{s}^{-1}$ (6 knots) Blom (1990) measured a total drag of $7.9 \mathrm{kN} \cdot \mathrm{m}^{-1}$ close to the estimated drag of 7.5 $\mathrm{kN} \cdot \mathrm{m}^{-1}$.
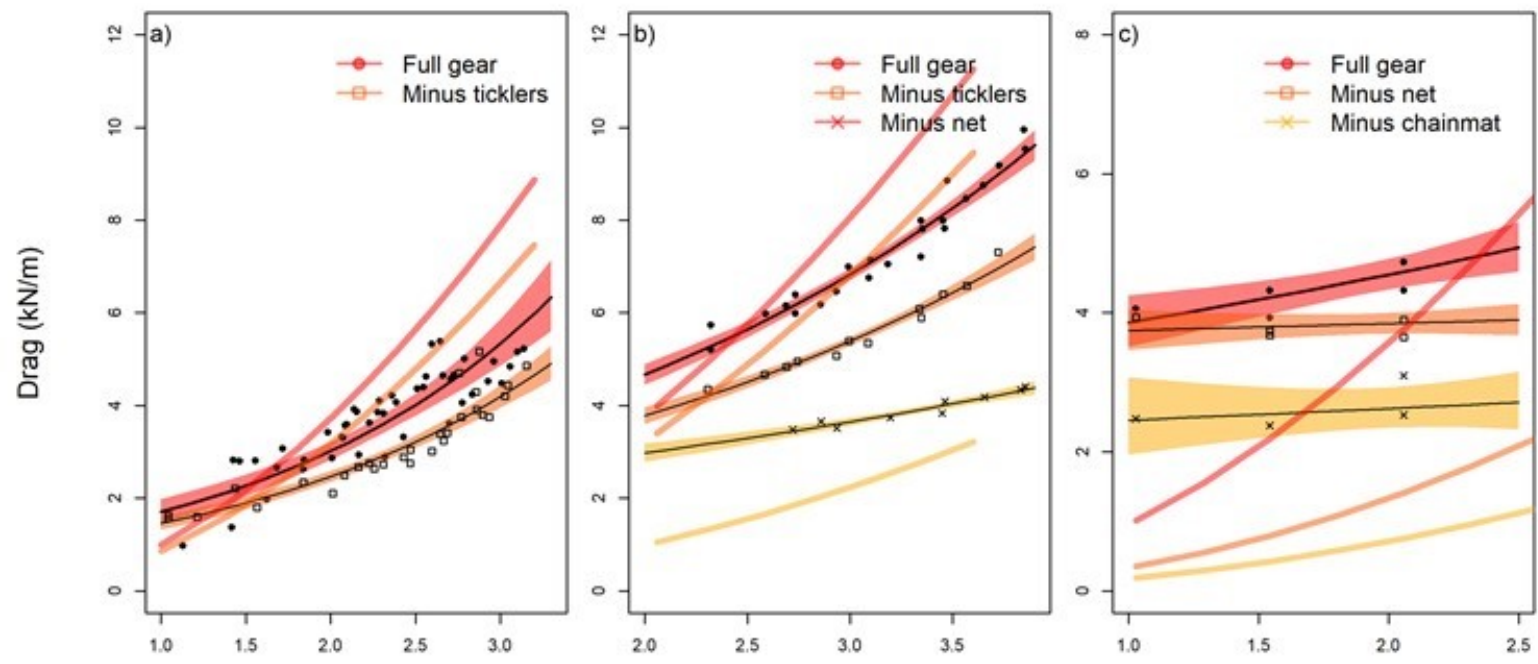

Speed $(\mathrm{m} / \mathrm{s})$

Figure 6. Comparison of modelled hydrodynamic drag (full lines) and measured total drag (black lines and 95\% confidence intervals) of a $11 \mathrm{~m}$ beam trawl: full gear and gear without shoe ticklers (panel a: Blom, 1982); a 12 m beam trawl: full gear, gear without ticklers, and gear without ticklers and net (panel b: Blom, 1990); and a 4m chain mat: full gear, gear without net, and gear without net and chain mat (Fonteyne in Paschen et al., 2000).

For tickler chain and chainmat components, the estimated drag closely matched the measured contribution to the total drag as shown in Figure 6. Also for the beam a close match was observed between the estimated hydrodynamic drag and the reduction in fuel use due to the replacement of the beam by a streamlined Sumwing. We expect that our approach will provide a reasonable approximation for gear components, such as trawl heads, beam, shoes, wing, electrode, tension relief cords, which match the basic shapes for which empirically estimated parameters are available. Further research is required to study the factors that contribute to the deviations between the estimated and observed hydrodynamic drag, in particular for net panels, and to critically test the principle of superposition (Paschen et al., 2000). It is possible that the turbulence induced in the wake of different gear elements may interfere which violates the assumption that the drag of the different gear elements is additive.

Although the estimated hydrodynamic drag of the net panels may be less certain, we expect that our methodology will be able to capture the relative differences between gears and gear components. In a comparison of the amount of sediment mobilized in the wake of a tickler chain beam trawl and a pulse trawl, Depestele et al. (2016) indeed found a good agreement between the numerical predictions and field estimates. Further support comes from a field study of the biogeochemical impacts of pulse and tickler chain beam by Tiano et al. (2019) who showed that tickler chain trawling reduced the sedimentary chlorophyll a by $83 \%$ as compared to $43 \%$ after PulseWing trawling. The difference is in line with the difference in estimated hydrodynamic drag of the bottom components of pulse and tickler chain beam trawls. 
Despite the inherent uncertainty in the estimated hydrodynamic drag, we are confident that the relative difference in drag of the conventional beam trawl gear and the pulse trawl will be robust. The dimension of the various beam trawls in this paper have been presented to active fishers and gear manufacturers and we are confident that they are representative for the fleet.

The transition from the tickler chain trawl to the pulse trawl resulted in a reduction in the hydrodynamic drag of the gear by $41 \%$ in large vessels and $5 \%$ in small vessels. The reduction is mainly due to the reduced towing speed and the replacement of tickler chains (or chain-mat) that run perpendicular to the towing direction by electrodes that run parallel to the towing direction. The reduction in towing speed is particularly important in large vessels because hydrodynamic drag scales with the square of the towing speed and towing speed of large vessels decreased from 3.29 to $2.53 \mathrm{~m} . \mathrm{s}^{-1}$ as compared to 2.66 to 2.39 $\mathrm{m} . \mathrm{s}^{-1}$ of small vessels.

To disentangle the effect of the change in towing speed from the contribution of the changes in the rigging of the trawl, the drag of the gear components has been calculated assuming a similar towing speed of pulse and tickler chain trawlers. The calculation showed that if both gears are towed at the same towing speed similar to the pulse trawls, the total drag of the pulse trawl is still lower but the difference decreases from $41 \%$ to $14 \%$. When smaller vessels would tow the tickler chain trawl at the same speed as the pulse trawl, the drag would be $5 \%$ higher than the drag of the tickler chain trawl.

The reduction in hydrodynamic drag due to the reduced towing speed and loss of tickler chains is partly counteracted by the higher twine surface area of the pulse trawl nets and the larger surface area of the ground rope in pulse trawls. The use of pulse gear required a rectangular matrix of electrode arrays to generate a stable electric field, constraining the type of ground rope to be used. Three types of ground ropes evolved. The PUL_R type, which is used by $49 \%$ of the vessels, allows fisher to use a 26 or 28 electrode arrays. The PUL_R_SR and PUL_U_SR types allow the deployment of 24 electrode arrays. The smaller number of electrode arrays implies a $\sim 10 \%$ narrower electric field which may reduce the catch efficiency. The reduction in catch efficiency, however, may be compensated by the smaller disk diameter of the additional sole rope which may increase the catch efficiency by reducing the chance that fish escape underneath the sole rope. The different rigging types used are related to the fishing grounds. Vessels from the northern harbours predominantly use the U-shaped ground rope and sole-rope. In the mid-south and mid-north vessels use a rectangular or U-shaped ground rope. Vessels from the south use rectangular ground ropes.

The reduction in hydrodynamic drag will result in a proportional reduction in the amount of sediment mobilized in the wake of the trawl if the traditional beam trawl and pulse trawl fishery have a similar spatial distribution pattern. Anecdotal information from the fishing industry suggests that pulse trawling has locally increased in muddy sediments. This could imply that the reduction in sediment mobilization due to the reduced hydrodynamic drag is less. A future analysis taking account the changes in distribution relative to the silt content of the sediments can quantify the change in sediment mobilization. The accuracy of the numerical prediction will be affected by the quality of the information of the dimensions of the gear components. In our study, an extensive data set was available of pulse trawls but the information on the conventional beam trawl and Sumwing trawls was more limited. In particular the sample size of the chainmat and the conventional beam trawl used by the small vessels was limited rendering the quantitative results for these trawls uncertain. 


\section{Acknowledgments}

This study was funded by the European Maritime and Fisheries Fund (EMFF) and the Netherlands Ministry of Agriculture Nature and Food Quality (LNV) (Grand/Award Number: 1300021172), the Netherlands Ministry of Agriculture Nature and Food Quality (BO-code), the Belgian EMFF project "Benthis-nationaal" and by the FP7-project BENTHIS (312088). The article does not necessarily reflect the views of the European Commission and does not anticipate the Commission's future policy in this area. Information on gear dimensions were provided by individual skippers. A. Lokker (Cooperatie Westvoorn), H. KleinWoolthuis (HFK engineering), A. van Wijk (van Wijk, BV) and M. Drijver are gratefully acknowledged for providing information on gear dimensions. 


\section{$6 \quad$ References}

Bergman, M. J. N., and Hup, M. 1992. Direct effects of beamtrawling on macrofauna in a sandy sediment in the southern North Sea. ICES Journal of Marine Science, 49: 5-11.

Blom, W. C. 1982. Weerstand van boomkortuigen. Rijksinstituut voor Visserijonderzoek, IJmuiden, the Netherlands. T082-03. $42 \mathrm{pp}$.

Blom, W. C. 1990. Weerstandscomponenten van een boomkortuig. Rijksinstituut voor Visserijonderzoek, IJmuiden, the Netherlands. TO90-01. 24 pp.

Bergman, M.J.N., Hup, M. 1992. Direct effects of beamtrawling on macrofauna in a sandy sediment in the southern North Sea. ICES Journal of Marine Science, 49:5-11.

Brent, R. 1973. Algorithms for Minimization without Derivatives. Englewood Cliffs N.J. Prentice-Hall.

Daan, N. 1997. TAC management in North Sea flatfish fisheries. Journal of Sea Research, 37:321-341.

de Haan, D., Fosseidengen, J.E., Fjelldal, P.G., Burggraaf, D., Rijnsdorp, A.D. 2016. Pulse trawl fishing: characteristics of the electrical stimulation and the effect on behaviour and injuries of Atlantic cod (Gadus morhua). ICES Journal of Marine Science, 73:1557-1569.

de Haan, D., Haenen, O., Chen, C., Hofman, A., van Es, Y., Burggraaf, D., Blom, E. 2015. Pulse trawl fishing: The effects on dab (Limanda limanda). IMARES Wageningen UR.

Depestele, J., Degrendele, K., Esmaeili, M., Ivanović, A., Kröger, S., O’Neill, F.G., Parker, R., Polet, H., Roche, M., Teal, L.R., Vanelslander, B., Rijnsdorp, A.D. 2019. Reducing mechanical disturbance in soft sediments by replacing tickler-chain SumWing for electrified PulseWing trawls ICES Journal of Marine Science, 76: 312-329.

Depestele, J., Ivanović, A., Degrendele, K., Esmaeili, M., Polet, H., Roche, M., Summerbell, K., Teal, L.R., Vanelslander, B., O'Neill, F.G. 2016. Measuring and assessing the physical impact of beam trawling. 2016. ICES Journal of Marine Science, 73:i15-i26.

Eigaard, O.R., Bastardie, F., Breen, M., Dinesen, G.E., Hintzen, N.T., Laffargue, P., Mortensen, L.O., Nielsen, J.R., Nilsson, H.C., O’Neill, F.G., Polet, H., Reid, D.G., Sala, A., Sköld, M., Smith, C., Sørensen, T.K., Tully, O., Zengin, M., Rijnsdorp, A.D. 2016. Estimating seabed pressure from demersal trawls, seines, and dredges based on gear design and dimensions. ICES Journal of Marine Science, 73:i27-i43

Engelhard, G.H. 2008. One hundred and twenty years of change in fishing power of English North Sea trawlers. in: Payne A., Cotter, J. and Potter, T, ed. Advances in Fisheries Science 50 years on from Beverton and Holt. London: Blackwell Publishing.

Ferro, R.S.T., 1981. The Calculation of the Twine Area of a Trawl Net. Scottish Fisheries Information Pamphlet, No 5: 1 - 6 .

Fonteyne, R., Polet, H. 1992. Huidige vistuigen en visserijmethodes in de Belgische Zeevisserij. Rijkstation voor Zeevisserij, Oostende. 40 pp. Oostende, Belgie: Rijkstation voor Zeevisserij.

Gillis, D.M., Rijnsdorp, A.D., Poos, J.J. 2008. Behavioral inferences from the statistical distribution of commercial catch: patterns of targeting in the landings of the Dutch beam trawler fleet. Canadian Journal of Fisheries and Aquatic Sciences, 65:27-37

Haasnoot, T., Kraan, M., Bush, S.R. 2016. Fishing gear transitions: lessons from the Dutch flatfish pulse trawl. ICES Journal of Marine Science, 73:1235-1243.

Hiddink, J.G., Jennings, S., Sciberras, M., Szostek, C.L., Hughes, K.M., Ellis, N., Rijnsdorp, A.D., McConnaughey, R.A., Mazor, T., Hilborn, R., Collie, J.S., Pitcher, C.R., Amoroso, R.O., Parma, A.M., Suuronen, P., Kaiser, M.J. 2017. Global analysis of depletion and recovery of seabed biota after bottom trawling disturbance. Proceedings of the National Academy of Sciences, 114:8301-8306.

Hoerner, S.F. 1965. Fluid-dynamic drag. Published by the author. 
Horwood, J. 1993. The Bristol Channel Sole (Solea solea (L)) - a Fisheries Case-Study. Advances in Marine Biology, 29: 215-367.

ICES, 2018. Report of the Working Group on Electric Trawling (WGELECTRA) 17-19 April 2018, IJmuiden, the Netherlands, pp 91.

ICES, 2018b. ICES Special Request Advice Greater North Sea Ecoregion sr.2018.08. 7 pp.

Jennings, S., Kaiser, M.J. 1998. The effects of fishing on marine ecosystems. Advances in Marine Biology, 34:201-352

Kaiser, M.J. 2019. Recent advances in understanding the environmental footprint of trawling on the seabed. Canadian Journal of Zoology, 97: 755-762.

Lindeboom, H.J., de Groot, S.J. eds. 1998. The effects of different types of fisheries on the North Sea and Irish Sea benthic ecosystems. Den Burg, Texel, The Netherlands: Netherlands Institute for Sea Research.

Lucchetti, A., Sala, A. 2012. Impact and performance of Mediterranean fishing gear by side-scan sonar technology. Canadian Journal of Fisheries and Aquatic Sciences, 69:1806-1816.

MacLennan, D.N. 1981. The drag of four-panel demersal trawls. Fisheries Research, 1:23-33

O'Neill, F.G., Ivanović, A. 2016. The physical impact of towed demersal fishing gears on soft sediments. ICES Journal of Marine Science, 73:i5-i14.

O'Neill, F.G., Summerbell, K.J. 2016. The hydrodynamic drag and the mobilisation of sediment into the water column of towed fishing gear components. Journal of Marine Systems, 164:76-84

Polet, H., Depestele, J. 2010. Impact assessment of the effects of a selected range of fishing gears in the North Sea. ILVO.

Poos, J.J., Turenhout, M.N.J., A. E. van Oostenbrugge, H., Rijnsdorp, A.D. 2013. Adaptive response of beam trawl fishers to rising fuel cost. ICES Journal of Marine Science, 70:675-684.

Poos, J.J., Hintzen, N.T., van Rijssel, J.C., Rijnsdorp, A.D. 2020. Efficiency changes in bottom trawling for flatfish species as a result of the replacement of mechanical stimulation by electric stimulation. ICES Journal of Marine Science, in press

Puig, P., Canals, M., Company, J.B., Martin, J., Amblas, D., Lastras, G., Palanques, A., Calafat, A.M. 2012. Ploughing the deep sea floor. Nature. 489:286-289

Rijnsdorp, A.D., Poos, J.J., Quirijns, F.J., HilleRisLambers, R., de Wilde, J.W., Den Heijer, W.M. 2008. The arms race between fishers. Journal of Sea Research, 60:126-138

Sangster and Breen, 1998. Gear performance and catch comparison trials between a single trawl and a twin rigged gear. Fisheries Research 36: 15-26.

Sciberras, M., Hiddink, J.G., Jennings, S., Szostek, C.L., Hughes, K.M., Kneafsey, B., Clarke, L., Ellis, N., Rijnsdorp, A.D., McConnaughey, R.A., Hilborn, R., Collie, J.S., Pitcher, C.R., Amoros, R.O., Parma, A.M., Suuronen, P., Kaiser, M.J. 2018. Response of benthic fauna to experimental bottom fishing: a global meta-analysis. Fish and Fisheries, 19:698-715

Soetaert, M., Boute, P.G., Beaumont, W.R.C. 2019. Guidelines for defining the use of electricity in marine electrotrawling. ICES Journal of Marine Science, 76: 1994-2007

Soetaert, M., Chiers, K., Duchateau, L., Polet, H., Verschueren, B., Decostere, A. 2015a. Determining the safety range of electrical pulses for two benthic invertebrates: brown shrimp (Crangon crangon L.) and ragworm (Alitta virens S.). ICES Journal of Marine Science, 72:973-980

Soetaert, M., Decostere, A., Polet, H., Verschueren, B., Chiers, K. 2015b. Electrotrawling: a promising alternative fishing technique warranting further exploration. Fish and Fisheries, 16:104-124.

Soetaert, M. Decostere, A., Verschueren, B., Saunders, J., Van Caelenberge, A., Puvanendran, V., Mortensen, A., Duchateau, L., Polet, H., Chiers, K. 2016a. Side-effects of electrotrawling: Exploring the safe operating space for Dover sole (Solea solea L.) and Atlantic cod (Gadus morhua L.). Fisheries Research, 177:95-103. 
Soetaert, M., de Haan, D., Verschueren, B., Decostere, A., Puvanendran, V., Saunders, J., Polet, H., Chiers, K. 2016b. Atlantic Cod Show a Highly Variable Sensitivity to Electric-Induced Spinal Injuries. Marine and Coastal Fisheries, 8:412-424.

Soetaert, M., Verschueren, B., Chiers, K., Duchateau, L., Polet, H., Decostere, A. 2016c. Laboratory Study of the Impact of Repetitive Electrical and Mechanical Stimulation on Brown Shrimp Crangon crangon. Marine and Coastal Fisheries, 8:404-411

Taal, C., Hoefnagel, E. 2010. Pulse trawl on flatfish as an alternative for beam trawl. The economic performance and the environmental impact of the innovative. Pulse trawl in comparison to the conventional Beam trawl. First International Symposium on Fishing Vessel Energy Efficiency E-Fishing, Vigo, Spain, May 2010.

Taal, C., Klok, A.J. 2014. Pulswing; Ontwikkeling van een vistuig voor platvis waarin puls-techniek met de SumWing is gecombineerd. Wageningen: LEI Wageningen UR (University \& Research centre)

Tiano, J. C., Witbaard, R., Bergman, M. J. N., van Rijswijk, P., Tramper, A., van Oevelen, D., and Soetaert, K. 2019. Acute impacts of bottom trawl gears on benthic metabolism and nutrient cycling. ICES Journal of Marine Science 76: 1917-1930.

Turenhout, M.N.J., Zaalmink, B.W., Strietman, W.J., Hamon, K.G. 2016. Pulse fisheries in the Netherlands; Economic and spatial impact study. Wageningen Economic Research, Report. Wageningen.

van Marlen, B., van Keeken, O.A., Dijkman Dulkes, H.J.A., Groeneveld, K., Pasterkamp, T.L., de Vries, M., Westerink, H.J., Wiegerinck, J.A.M. 2009. Vergelijking van vangsten en brandstofverbruik van kotters vissend met conventionele en SumWing-boomkorren. Wageningen IMARES Rapport C023/09

van Marlen, B., Wiegerinck, J.A.M., van Os-Koomen, E., van Barneveld, E. 2014. Catch comparison of flatfish pulse trawls and a tickler chain beam trawl. Fisheries Research, 151:57-69

van Stralen, M.R. 2005. De Pulskor. MarinX-rapport 2005.2.6

$\mathrm{Xu}, \mathrm{Z}$., Huang, S. 2014. Numerical investigation of mooring line damping and the drag coefficients of studless chain links. Journal of Marine Science and Application. 13:76-84; 2014 


\section{Annex}

Table 1. Gear components, hydrodynamic drag coefficient and equation number used to estimate the hydrodynamic drag.

\begin{tabular}{lcc}
\hline Gear component & $\mathrm{cd}$ & Equation \\
\hline Shoe & 1.05 & 1 \\
Nose & 1.1 & 1 \\
Beam & 1.1 & 1 \\
Ground rope & 1.1 & 2 \\
Tickler chain & 2.3 & 2 \\
Electrode in water & 0.8 & 2 \\
Electrode on seafloor & 1.1 & 1 \\
Tension relief cord & 0.8 & 2 \\
Net panels & - & 12 \\
\hline
\end{tabular}


Table 2. Dimensions of beam and shoes and the SumWing and nose as used in the beam trawl fishery for flatfish in the North Sea applying mechanical stimulation.

\begin{tabular}{|c|c|c|c|c|c|c|c|c|c|c|}
\hline \multirow[t]{2}{*}{ Element } & \multirow[t]{2}{*}{ Metric } & \multirow[t]{2}{*}{ Unit } & \multicolumn{3}{|c|}{ Small vessels $(<=221 \mathrm{~kW})$} & \multirow[b]{2}{*}{$\mathrm{n}$} & \multicolumn{4}{|c|}{ Large vessels (>221 kW) } \\
\hline & & & median & $\min$ & $\max$ & & median & $\min$ & $\max$ & $\mathrm{n}$ \\
\hline \multirow[t]{2}{*}{ Beam } & length & $\mathrm{m}$ & 4.5 & 4.5 & 4.5 & & 12 & 12 & 12 & \\
\hline & diameter & $\mathrm{m}$ & 0.15 & & & 4 & 0.24 & & & 7 \\
\hline \multirow[t]{2}{*}{ Shoe tickler beam } & Frontal surface area & $\mathrm{m}^{2}$ & 0.054 & 0.054 & 0.054 & 2 & 0.063 & 0.045 & 0.072 & 6 \\
\hline & height & $\mathrm{m}$ & 0.60 & 0.60 & 0.60 & 2 & 0.70 & 0.50 & 0.80 & 6 \\
\hline Shoe pulse beam & Frontal surface area & $\mathrm{m}^{2}$ & 0.038 & 0.030 & 0.040 & 8 & 0.060 & 0.060 & 0.060 & 2 \\
\hline \multirow[t]{3}{*}{ Wing } & depth & $\mathrm{m}$ & 0.94 & & & & 1.07 & & & \\
\hline & Max. height & $\mathrm{m}$ & 0.17 & & & & 0.20 & & & \\
\hline & Height above sea floor & $\mathrm{m}$ & 0.45 & & & & 0.45 & & & \\
\hline \multirow[t]{3}{*}{ Nose } & length & $\mathrm{m}$ & 2.89 & & & & 3.40 & & & \\
\hline & Contact area sea bed & $\mathrm{m}^{2}$ & 0.07 & & & & 0.14 & & & \\
\hline & Frontal surface area & $\mathrm{m}^{2}$ & 0.024 & & & & 0.036 & & & \\
\hline
\end{tabular}


Table 3. Dimensions of fishing gears used in the beam trawl fishery for flatfish in the North Sea applying mechanical stimulation.

\begin{tabular}{|c|c|c|c|c|c|c|c|c|c|c|}
\hline \multirow[t]{2}{*}{ Element } & \multirow[t]{2}{*}{ Metric } & \multirow[t]{2}{*}{ Unit } & \multicolumn{4}{|c|}{ Small vessels $(<=221 \mathrm{~kW})$} & \multicolumn{4}{|c|}{ Large vessels (>221 kW) } \\
\hline & & & median & $\min$ & $\max$ & $\mathrm{n}$ & median & $\min$ & $\max$ & $\mathrm{n}$ \\
\hline \multirow[t]{2}{*}{ Ticklers shoe } & number & number & 6.5 & 6 & 7 & 2 & 8.8 & 7 & 11 & 13 \\
\hline & diameter & $\mathrm{mm}$ & 25 & 25 & 25 & 1 & 22.7 & 18 & 26 & 12 \\
\hline \multirow[t]{2}{*}{ Ticklers net } & number & number & 5 & 4 & 6 & 2 & 10.9 & 9 & 17 & 13 \\
\hline & diameter & $\mathrm{mm}$ & & & & & 16.9 & 12 & 22 & 12 \\
\hline Ground gear & length & $\mathrm{m}$ & 16 & 16 & 16 & 2 & 35.4 & 34 & 38.5 & 10 \\
\hline Disks centre section & diameter & $\mathrm{m}$ & $0.24^{1}$ & & & & 0.35 & 0.25 & 0.5 & 9 \\
\hline Disks end sections & diameter & $\mathrm{m}$ & $0.15^{1}$ & & & & 0.25 & 0.22 & 0.28 & 9 \\
\hline
\end{tabular}

${ }_{1}$ Pers comm Arie Lokker 
Table 4. Dimensions chain mat beam trawls used by small and large vessels

\begin{tabular}{|c|c|c|c|c|c|c|c|c|c|c|}
\hline \multirow[t]{2}{*}{ Element } & \multirow[t]{2}{*}{ Metric } & \multirow[t]{2}{*}{ Unit } & \multicolumn{3}{|c|}{ Small vessels $(<=221 \mathrm{~kW})$} & \multirow[b]{2}{*}{$\mathrm{n}$} & \multicolumn{4}{|c|}{ Large vessels $(>221 \mathrm{~kW})$} \\
\hline & & & median & $\min$ & $\max$ & & median & $\min$ & $\max$ & $\mathrm{n}$ \\
\hline Trawl & length & $\mathrm{m}$ & 4 & 4 & 4 & 2 & 12 & 12 & 12 & 2 \\
\hline \multirow[t]{2}{*}{ Chain longitudinal } & Number & number & 12.5 & 12 & 13 & 2 & 25.5 & 21 & 30 & 2 \\
\hline & diameter & $\mathrm{m}$ & 0.011 & & & 2 & 0.025 & 0.023 & 0.026 & 2 \\
\hline \multirow[t]{2}{*}{ Chain latitudinal } & Number & number & 10 & 8 & 12 & 2 & 16 & 16 & 16 & 2 \\
\hline & diameter & $\mathrm{m}$ & 0.0205 & 0.019 & 0.022 & 2 & 0.016 & 0.016 & 0.016 & 2 \\
\hline \multirow[t]{3}{*}{ Ticklers shoe } & number & number & 2 & & & 2 & 2 & 1 & 3 & 2 \\
\hline & length & $\mathrm{m}$ & 8 & 5 & 11 & 2 & 19 & 19 & 19 & 1 \\
\hline & diameter & $\mathrm{m}$ & 0.020 & 0.018 & 0.022 & 2 & 0.022 & 0.018 & 0.026 & 2 \\
\hline \multirow[t]{3}{*}{ Ticklers chain mat } & number & number & & & & & 4 & 4 & 4 & 1 \\
\hline & length & $\mathrm{m}$ & & & & & 4 & 2 & 5 & 1 \\
\hline & diameter & $\mathrm{m}$ & & & & & 0.018 & 0.018 & 0.018 & 1 \\
\hline \multirow[t]{2}{*}{ Ground gear 1} & length & $\mathrm{m}$ & 12.5 & 12 & 13 & 2 & 20.5 & 20 & 21 & 2 \\
\hline & diameter & $\mathrm{m}$ & 0.024 & 0.022 & 0.026 & 2 & 0.0245 & 0.024 & 0.025 & 2 \\
\hline \multirow[t]{2}{*}{ Ground gear 2} & length & $\mathrm{m}$ & 10.25 & 10 & 10.5 & 2 & 19 & 20 & 18 & 2 \\
\hline & diameter & $\mathrm{m}$ & 0.022 & 0.018 & 0.026 & 2 & 0.021 & 0.020 & 0.021 & 2 \\
\hline
\end{tabular}


Table 5. Twine surface area $\left(\mathrm{m}^{2}\right)$ per meter beam length by gear and rigging type

\begin{tabular}{|c|c|c|c|c|}
\hline Rigging & Engine class & mean & sd & $\mathrm{n}$ \\
\hline \multicolumn{5}{|l|}{ Tickler chain beam trawl } \\
\hline Tickler & large & 4.73 & 0.71 & 12 \\
\hline Chain mat & large & 3.74 & 0.75 & 2 \\
\hline Tickler & small & 4.64 & 1.62 & 3 \\
\hline $\begin{array}{l}\text { Chain mat } \\
\text { Pulse trawl }\end{array}$ & small & 3.93 & & 1 \\
\hline PUL_R: Rectangular & large & 5.64 & 1.43 & 8 \\
\hline PUL_R: Rectangular-trouser & large & 5.33 & 1.20 & 5 \\
\hline PUL_R_SR: Rectangular-sole rope & large & 5.28 & 1.57 & 3 \\
\hline PUL_U_SR: U-sole rope & large & 6.68 & 0.73 & 20 \\
\hline PUL_R: Rectangular & small & 6.10 & 0.88 & 3 \\
\hline
\end{tabular}


Table 6. Number of vessels and the types of pulse trawl (Pulse-wing, Pulse beam trawl) and type of rigging used in the Dutch pulse trawl fleet of large and small vessels (pulse_trawl_dimension.xls).

\begin{tabular}{|c|c|c|c|c|}
\hline & \multirow{2}{*}{\multicolumn{2}{|c|}{$\begin{array}{l}\text { Large vessels } \\
(>221 \mathrm{~kW})\end{array}$}} & \multirow{2}{*}{\multicolumn{2}{|c|}{$\begin{array}{l}\text { Euro cutters } \\
(<=221 \mathrm{~kW})\end{array}$}} \\
\hline & & & & \\
\hline & Pulse wing & $\begin{array}{l}\text { Pulse beam } \\
\text { trawl }\end{array}$ & Pulse wing & $\begin{array}{l}\text { Pulse beam } \\
\text { trawl }\end{array}$ \\
\hline \multicolumn{5}{|l|}{ Rectangular ground gear } \\
\hline PUL_R_SR: Sole rope & 9 & 1 & & \\
\hline PUL_R & $13^{(1)}$ & 6 & 3 & $12^{(2)}$ \\
\hline Unknown & \multicolumn{2}{|c|}{1} & & 1 \\
\hline \multicolumn{5}{|l|}{ U-shape ground gear } \\
\hline PUL_U_SR: Sole rope & 23 & $3^{(3)}$ & & \\
\hline Unknown & \multicolumn{2}{|c|}{3} & \multicolumn{2}{|c|}{1} \\
\hline Total & \multicolumn{2}{|c|}{59} & \multicolumn{2}{|c|}{17} \\
\hline
\end{tabular}

(1) including three vessels with a trouser trawl; (2) including one vessel with a roller shoe; (3) including two vessels with a roller shoe 
Table 7. Pulse trawl ground rope characteristics of the rigging types for small ( $<=221 \mathrm{~kW})$ and large ( $>221 \mathrm{~kW}$ ) vessels. Ground rope types comprise of a rectangular ground rope (PUL_R), a rectangular ground rope with a sole rope (PUL_R_SR) and a U-shaped ground rope with a sole rope (PUL_U_SR).

\begin{tabular}{|c|c|c|c|c|c|c|c|c|}
\hline \multirow[b]{2}{*}{ Gear components } & \multicolumn{4}{|c|}{ Length (m) } & \multicolumn{4}{|c|}{ Diameter (mm) } \\
\hline & median & $\min$ & $\max$ & $\mathrm{n}$ & median & $\min$ & $\max$ & $\mathrm{n}$ \\
\hline \multicolumn{9}{|l|}{ PUL_R, small vessels } \\
\hline Total ground rope & 15.4 & 15.4 & 21.1 & 13 & & & & \\
\hline Latitudinal part & 4.0 & 3.7 & 5.6 & 13 & 20 & 12 & 30 & 13 \\
\hline Longitudinal parts & 5.7 & 5.7 & 7.8 & 13 & 15 & 10 & 20 & 2 \\
\hline \multicolumn{9}{|l|}{ PUL_R, large vessels } \\
\hline Total ground rope & 24 & 24 & 24 & 6 & & & & \\
\hline Latitudinal part & 10 & 10 & 10 & 6 & 20 & 13 & 24 & 18 \\
\hline Longitudinal parts & 7 & 7 & 7 & 6 & 15 & 12 & 22 & $(A L)$ \\
\hline \multicolumn{9}{|l|}{ PUL_R_SR, large vessels } \\
\hline Total ground rope & 27.6 & 24 & 29.6 & 7 & & & & \\
\hline Latitudinal part & 9 & 9 & 10.2 & 7 & 20 & 15 & 30 & 10 \\
\hline Longitudinal parts & 9 & 7 & 10 & 7 & 20 & 10 & 20 & 3 \\
\hline Sole rope $(\mathrm{m})$ & 9.5 & 9.5 & 9.5 & 3 & 10 & 5 & 20 & 10 \\
\hline \multicolumn{9}{|l|}{ PUL_U_SR, large vessels } \\
\hline Total ground rope & 30.5 & 30 & 32.5 & 13 & & & & \\
\hline Middle section centre & \multirow{2}{*}{10} & \multirow{2}{*}{10} & \multirow{2}{*}{10} & \multirow{2}{*}{13} & 24 & 18 & 30 & 16 \\
\hline Middle section ends & & & & & 18 & 13 & 22 & 16 \\
\hline Wing parts & 8.3 & 7.3 & 10.3 & 13 & 15 & 10 & 15 & 14 \\
\hline Sole rope & 9.5 & 9.5 & 10.4 & 19 & 15 & 10 & 20 & 21 \\
\hline
\end{tabular}

(AL) personal communication Arie Lokker 
Table 8. Towing speed $\left(\mathrm{m} . \mathrm{s}^{-1}\right)$ : mean, standard deviation and number of observations by gear and engine class.

\begin{tabular}{lccccccc}
\hline & \multicolumn{3}{c}{ Small vessels $(<221 \mathrm{~kW})$} & & \multicolumn{3}{c}{ Large vessels $(>221 \mathrm{~kW})$} \\
& mean & sd & $\mathrm{n}$ & mean & sd & $\mathrm{n}$ \\
\hline Gear & & & & & & & \\
Chain-mat & 2.64 & 0.25 & 1087 & 3.10 & 0.13 & 2102 & 12483 \\
Tickler chain & 2.66 & 0.38 & 3930 & 3.29 & 0.23 & 0.14 & 11387 \\
Pulse trawl & 2.39 & 0.16 & 4286 & 2.53 & 0.53 \\
\hline
\end{tabular}


Table 9. Hydrodynamic drag ( $\mathrm{kN} . \mathrm{m}^{-1}$ ) of major gear components of tickler chain trawlers (Tickl) and pulse trawls (Pul). Tickler, electrodes include chainmat and tension relief cords. The hydrodynamic drag of the Sumwing is $0.09 \mathrm{kN} \cdot \mathrm{m}^{-1}$.

\begin{tabular}{cccccccccc}
\hline $\begin{array}{c}\text { Gear type and } \\
\text { rigging }\end{array}$ & $\begin{array}{c}\text { Engine } \\
\text { class }\end{array}$ & Beam ${ }^{1}$ & $\begin{array}{c}\text { Net } \\
\text { top }\end{array}$ & $\begin{array}{c}\text { Net } \\
\text { bottom }\end{array}$ & $\begin{array}{c}\text { Ground } \\
\text { gear }\end{array}$ & $\begin{array}{c}\text { Ticklers } \\
\text { Electrodes }\end{array}$ & $\begin{array}{c}\text { Shoe } \\
\text { nose }\end{array}$ & $\begin{array}{c}\text { Total } \\
\text { Total } \\
\text { bottom }\end{array}$ \\
\hline Small vessels (<=221 kW) & & & & & & & & & \\
Tckl_V-net & small & 0.83 & 1.99 & 2.34 & 0.38 & 0.69 & 0.03 & 6.3 & 3.4 \\
Tckl_Chainmat & small & 0.53 & 1.47 & 2.17 & 0.56 & 0.94 & 0.03 & 5.7 & 3.7 \\
\hline Pul_R & small & 0.53 & 2.50 & 2.21 & 0.59 & 0.09 & 0.03 & 6.0 & 2.9 \\
\hline Large vessels (>221 kW) & & & & & & & & & \\
Tickl_V-net & large & 1.43 & 3.25 & 3.13 & 0.77 & 2.26 & 0.04 & 10.9 & 6.2 \\
Tickl_Chainmat & large & 1.27 & 2.09 & 2.46 & 1.40 & 2.40 & 0.04 & 9.7 & 6.3 \\
\hline Pul_R & large & 0.63 & 2.31 & 2.50 & 0.60 & 0.11 & 0.02 & 6.2 & 3.2 \\
Pul_R_trouser & large & 0.63 & 2.40 & 2.12 & 0.56 & 0.13 & 0.02 & 5.9 & 2.8 \\
Pul_R_SR & large & 0.63 & 2.29 & 2.97 & 0.86 & 0.11 & 0.02 & 6.9 & 4.0 \\
Pul_U_SR & large & 0.63 & 2.36 & 3.28 & 0.74 & 0.11 & 0.02 & 7.1 & 4.1 \\
Pulse combined & large & 0.63 & 2.34 & 2.99 & 0.72 & 0.11 & 0.02 & 6.8 & 3.8 \\
\hline
\end{tabular}




\section{Justification}

Report C056/20

Project Number: 4314100010.

The scientific quality of this report has been peer reviewed by a colleague scientist and a member of the Management Team of Wageningen Marine Research

Approved: $\quad$ Dr. J.C. van Rijssel

\section{Researcher}

Signature:

Date:

26th of June, 2020

Approved: $\quad$ Dr. Ir. T.P. Bult

Director

Signature:

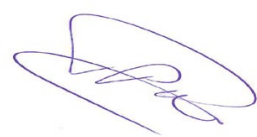

Date:

26th of June, 2020 
Wageningen Marine Research

$\mathrm{T}+31(0) 317480900$

E: marine-research@wur.nl

www.wur.eu/marine-research

Visitors' address

- Ankerpark 271781 AG Den Helder

- Korringaweg 7, 4401 NT Yerseke

- Haringkade 1, 1976 CP IJmuiden
With knowledge, independent scientific research and advice, Wageningen Marine Research substantially contributes to more sustainable and more careful management, use and protection of natural riches in marine, coastal and freshwater areas.
Wageningen Marine Research is part of Wageningen University \& Research. Wageningen University \& Research is the collaboration between Wageningen University and the Wageningen Research Foundation and its mission is: 'To explore the potential for improving the quality of life' 